\title{
Change, Challenge and China: an Analysis of Competition in the North American TEXTILE AND APPAREL INDUSTRIES
}

\author{
By Katrina D. Connolly
}

Abstract: Media, manufacturers, and politicians are blaming China for intensified competition, downward pressure on prices and job loss in the U.S. manufacturing sector. A brief history of textile and apparel trade suggests that people over-reacted to a surge of Chinese imports in 2005 because of a historical focus on defining single countries as threats to domestic markets. Approaching trade policy from a broader perspective reveals that bilateral thinking overstates China as a threat. A broader approach studies how trade policies interact to create changes in market prices rather than a single country. To illustrate these effects, an economic analysis of the North American Free Trade Agreement first explains how this regional trade policy bolstered higher prices and demand for North American textile and apparel products. Economic models then explain how a global policy that liberalized trade, Agreement on Textiles and Clothing, undermined NAFTA's benefits and enhanced the competitive pressure perceived by these manufacturers. The article concludes that as one of many countries liberalized by the ATC, China plays a smaller role than the public assumes in diminishing NAFTA's benefits as perceived by North American textile and apparel manufacturers.

\section{INTRODUCTION}

In recent years, American textile manufacturers have perceived both an increased level of competition from overseas manufacturers and a drop in the price of their manufactured goods. ${ }^{1}$ At the same time, the U.S. market experienced an import surge of Chinese apparel and textile products in 2005, leading media, manufacturers and policymakers to pinpoint China as the main threat to the industry. ${ }^{2}$ In fact, China is not the threat that manufacturers and policymakers assume it to be. The competition experienced by U.S. textile companies is far broader than the contribution of one

Katrina D. Connolly is a second-year doctoral student at The George Washington University School of Public Policy and Public Administration. She explores her interest in the making and impact of public policies in a globalizing world within her concentration of international urban policy. She currently works as a research assistant for Professor Michael Wiseman. She received a B.A. in International Studies from Emory University in 2003. country. Moreover, the idea that imposing restrictions on China will protect U.S. manufacturers is unrealistic.

This article attempts to expose the flawed reasoning that underpins current expectations about trade restrictions on China and give an accurate description of China's impact on world trade. The article also attempts to describe the real reasons behind the perceived drop in price of manufactured goods: a complex interaction between two trade agteements, the North American Free Trade Agreement (NAFTA), a regional trade agreement, and Agreement on 'Textiles and Clothing (ATC), a global trade agreement. The economic analysis of these two agreements accepts trade rules as given and does not address concerns over fairness or compliance with trade rules. Finally, this article suggests that competition in manufacturing is here to stay; thus, North American manufacturers

The author would like to thank Dr. Judith Dean for guidance in initial research, Professor John Forrer for big-picture discussions, and Professor Jill Kasle for her writing expertise. She would also like to thank the student editors for their diligent work and thoughtful suggestions: Jessy Defenderfer, Scott Olson, Christine Brown, and Hayley Trakas. 
would benefit by viewing China not as an enemy but as the source of a new market for the sale of North American goods.

\section{History of TeXTile and APPAREL} Trade

Since China joined the World Trade Organization (WTO) in 2001, newspaper articles and congressional bills have described Chinese trade relations as problematic for U.S. manufacturers. Specifically, journalists and lawmakers discussed market-distupting import surges from China, a widening of the U.S. trade deficit with China, the undervaluing of Chinese currency, and the threat of China's ability to function as a non-market economy, employing subsidies and below-cost prices. ${ }^{3} \quad$ Therefore, the import surge of Chinese textile and apparel products that occurred in the U.S. market in 2005 alarmed U.S. manufacturers and policymakers. ${ }^{4}$ The best way to grasp the concern that Chinese imports produced in the North American apparel and textile markets is through understanding trade policy in these markets.

Trade policies in the textile and apparel industries began after World War II when Western developed countries perceived that emerging economies would disrupt their markets with cheaper products. In 1956, the U.S. pressured Japan into limiting its quantity of cotton textile exports in order to protect U.S. textile manufacturers (Spinanger 1999, 456). The United Kingdom followed suit and began requesting restrictions on textile products from Hong Kong, India, and Pakistan (Francois and Spinanger 2004, 1).

These arrangements expanded to other countries, and the General Agreements on Tariffs and Trade (GATT) organized the array of existing bilateral agreements into Short-Term Arrangements (STAs) in 1961.5 The STAs initially aimed to open restricted markets with minimal market disruption. Market disruption, a concept defined by GATT's Contracting Parties in 1960, describes an import surge, a perceived import surge, or a threat of a surge from a single, identifiable source (Francois and Woerz 2006, 2). However, instead of opening markets to new competitors incrementally to prevent market disruption, the STAs extended into a Long-Term Arrangement in 1962 that lasted until the Multi-Fiber Agreement (MFA) supplanted it in 1974 (Francois and Woerz 2006, 2 and 18).

The MFA responded to rapid growth of textile and apparel industries (mostly in developing countries) by providing a cohesive package of restraints to protect domestic industries of developed countries. Renewed every four to five years, the MFA established a global system of quotas (restrictions on quantities exported) for the textile and apparel industries based on bilaterally negotiated agreements (Francois and Woerz 2006, 2, 12 , and 18). As a result, the MFA expanded drastically over the years. In 1974, the U.S. maintained quantitative restrictions in textile trade on 18 countries whose average share of U.S. imports totaled 4 percent. By 1985, the U.S. had quantitative restrictions on 21 countries which averaged 74 percent of the share of U.S. imports in the textiles and apparel industries combined (Dean 2002, 6). These numbers not only illustrate the expansion of the MFA but also predict the large impact that an elimination of the quantitative restrictions would have on the textiles and apparel markets.

\section{Agreement on Textiles and Clothing}

The Contracting Parties of GAT'T (to become the WTO in 1995) negotiated trade liberalization during the Uruguay Round (1986-1995). In 1993, they decided to eliminate all quantitative restrictions with an agreement designed to mitigate the possible market disruption that could occur with such a drastic policy change. The result, Agreement on Textiles and Clothing (ATC), phased out the MFA quantitative restrictions over a 10-year period (1995-2005) with four phases. The ATC's four phases mandated different levels of liberalization, releasing quantitative restrictions on 16 percent of each member's 1990 import volume by January 1, 1995; 17 percent by 1998; 18 percent by 2002; and the remaining 49 percent of the country's 1990 import volume by January 1, 2005 (Francois and Woerz 2006, 3; Spinanger 1999, 457). 
The ATC design left nearly half of the liberalization for the final three years. Furthermore, the importing country could choose which products to liberalize in each phase, provided the phase represented four groupings: tops and yarn, fabrics, made-up textile products, and clothing (Ftancois and Woerz 2006, 3; Spinanger 1999,457$)$. Importing countries generally took advantage of this choice and saved all substantive liberalization for the final phase. In the early phases, countries released official quotas that did not actually limit production potential of the exporting country. This back-loading in the phase-out process ultimately nullified the intended benefit of the phase-outpreventing market distuption (Francois and Spinanger 2004, 2).

When China joined the WTO in 2001 in the middle of this phase-out, the WTO subjected Chinese products to quota liberalization just like other WTO members. Back-loading the phase-out and China's shorter time table (2001-2005) led to the import surge of Chinese products in the U.S. in 2005 because substantive liberalization occurred suddenly (Francois and Woerz 2006, 10-13). Trade experts expected the import surge for these reasons and included a clause in China's WTO membership that allowed the U.S. to reinstate quotas until 2008 (Office of Textiles and Apparel 2005a). Thus, the U.S. was prepared to respond to the import surge with policy, but the historical concept of market distuption from a single country contributed to raising public concern over the surge of Chinese imports in 2005.

\section{North American Free Trade}

\section{Agreement}

In addition to the ATC, the North Ametican Free Trade Agreement (NAFTA) had a significant impact on the shape of textile and apparel trade. Enacted in 1994, NAFTA created a regional trade block with trade preferences designed to facilitate trade between the U.S., Mexico, and Canada, ${ }^{8}$ NAFTA, in its simplest form, gave preference to Mexican textile and apparel producers in the U.S. market.
NAFTA relaxed restrictions on Mexico in a trade environment where the U.S. restricted market access by other countries through the use of tariffs and quotas; this combination gave Mexican producers preferential access to U.S. markets over producers in competing countries. Based on neo-classical economic theory, these restrictions on competitive suppliers in other countries resulted in increased U.S. market prices (see Figure 1). Mexico's preferential access allowed the country's producers to sell goods in the U.S. at a higher price than the price that would exist in the absence of restrictions on other competitors (see Figure 2). Moreover, this preferential access created a higher demand for Mexican products than typically would exist without the restrictions on competitors, another clear example of neo-classical economic theory when market demand exceeds restricted supply (see Figure 3). In other words, Mexican producers sold more goods at a higher price in the U.S. market than they could have without NAFTA's preferential access.

Mexican export data from the U.S. Office of Textiles and Apparel confirm that Mexico received trade preference under NAFTA. In the years leading up to NAFTA from 1989 to 1993, Mexico's quantity of textile and apparel exports to the U.S. increased by 73 percent and increased its share of the U.S. market increased by 1 percentage point. These numbers drastically jumped with NAFTA's enactment. From 1993 to 1997 , Mexico's textile and apparel exports to the U.S. increased by 307 percent, and its share of the U.S. import market increased by 8.6 percentage points.

Mexico's trade preference is a crucial part of North American textile and apparel industries because of a clause in NAFTA, the Rules of Origin (ROO). ROO mandated that inputs of a product bound for a NAFTA country must originate from the importing country. For example, Mexican producers of fabric must use yarn made in the U.S. in order to sell that fabric in the U.S. Therefore, ROO required Mexican producers to buy from the U.S. in order to sell in the U.S. matket. In effect, ROO created more buyers for U.S. textile and apparel intermediary goods - goods used as inputs for a product (Cadot et al. 2002, 6 and 25). As a result of the provisions of ROO, Mexico accounted for a thitd of world demand for U.S. exports of textiles and apparel products in 2002. No 
other country imported anywhere close to that amount from the U.S. at that time. ${ }^{10}$

In practice, the effect of the Mexico-U.S. ROO differed from its intended purpose. The general purpose of any ROO, common in trade preference agteements, is to prevent countries outside a trade block from using a member country's preferential access within the block (Cadot $e t$ al. 2002, 2 and Anson et al. 2005, 502). Accordingly, the Mexico-U.S. ROO sought to keep a country restricted from the U.S. market from shipping its goods to the U.S. through Mexico. However, in effect, the ROO kept the cost of production higher than it would have been for Mexican producers if Mexico did not participated in NAFTA. ROO required Mexican producers to buy U.S. intermediary goods that sold at a higher price than competitors' products, which raised Mexico's production costs (Cadot et al. 2005, 2-3). The fact that 79 percent of Mexico's textile imports came from the U.S. in 2002 even though U.S. textiles sold higher than world market price suggests that Mexico benefited in return for the higher production costs (Cadot et al. 2002, 6 and 25). In effect, ROO created a relationship of dependency for Mexican producers based on preferential access to the U.S. market (Cadot et al. 2002, 8-9; Cadot et al. 2005, 2; Anson et al. 2005, 507). Mexican producers needed to receive a higher price in order to comply with ROO.

At face value, the purpose of ROO offered a beneficial agreement for Mexican and U.S. textile and apparel manufacturers, but it made them dependent on preferential access to maintain the higher level of production and price. Mexico was, in essence, buying more expensive inputs and selling more expensive goods. Mexico could sell more expensive goods to the U.S. because trade preference gave Mexico higher border prices than other restricted countries. However, Mexico needed a higher border price to comply with ROO; the question is how much (Cadot $e t$ al. 2005, 4). Cadot et al. (2005) estimated the amount of trade preference that Mexican apparel producers needed in order to give up their theoretical ability to buy inputs from and sell finished goods to the rest of the world. Cadot et al. (2005) estimated that Mexico's producers needed a margin of 7 percent preferential access, and they had about a 10 percent preferential market access rate during the 1990's (19-20). Therefore, the higher price Mexican apparel producers enjoyed from their preferential access to the U.S. market barely made up for the higher cost of production due to the Rules of Origin (Cadot et al. 2005, 20) (see Figure 4). In other words, Mexico's trade preference under NAFTA just compensated its producers for complying with ROO.

The history of textile and apparel trade policy reveals an undetlying tendency towards thinking that a single country causes changes in market price. Interpreting the Chinese import surge of 2005 under this assumption would understandably cause alarm. However, the existence of complex regional and global trade rules require a broader approach towards understanding changes in the market. Competitive pressure in the textile and apparel markets intensified around 2005 because countries back-loaded the phaseout of quotas, which saved the biggest impacts of the ATC on markets for 2005 (see note 6). Meanwhile, NAFTA's regional trade block bolstered apparel and textile trade between member countries while quotas restricted competitors in other countries in the 1990s. In effect, NAFTA set up the North American apparel and textile industries for a larger fall when the ATC lifted the quotas off restricted countries because the increased competition lowered prices and reduced Mexico's trade preference.

\section{A Broader Approach: The Interaction of Trade Policies}

In essence, the ATC undermines the benefits of NAFTA-specifically, the trade preferences-a fact which redounded to the discomfort of North American manufacturers. Cadot et al.'s (2005) research provides insight into how the ATC diminishes Mexico's trade preference and reduces NAFTA's benefits. They use econometric analysis to explore the effects of ATC completion on Mexico. The authors compare models that both control and do not control for Rules of Origin (4-5, 13-14). In the model that controls for ROO, Mexico's apparel producers retain only half their preference margin (Cadot et al. 2005, 5). Cadot et al.'s findings suggest that half of Mexico's preference margin comprises only 5 percent but Mexico needs a 7 percent preference margin to compensate for ROO. 
Cadot $e t$ al.'s (2005) findings imply that as Mexico's trade preference diminishes with the ATC phase-out of quotas, ROO will make Mexico's apparel production too costly to compete with producers who can use cheaper inputs than those from U.S. producers. As a result, if the ATC diminishes trade preference by lifting quota restrictions from competitors, it will undermine NAFTA's benefits and boost competitive pressure on North American producers.

Francois and Woerz (2006) echo Cadot et al's (2005) findings. When applied to the case of Mexico, Francois and Woerz's (2006) study suggests that as the ATC releases suppliers from quantitative restrictions, Mexico will lose the trade preference previously created by the restrictions on other countries (13). U.S. manufacturers will then lose buyers and face cheaper competition that sells at a lower price in the U.S. market.

Given that the ATC reduces the trade preference built into NAFTA as well as the benefits of higher prices, how much of these effects can be attributed to China? Public debate about trade liberalization as reflected in newspapers and congressional proposals suggests that China causes many of the adverse impacts of trade liberalization in North American markets, including job loss and downward pressure on prices. However, evidence suggests that this conclusion ignores the broader impacts of the trade agreements and overstates the importance of China in the North American textile and apparel industries.

\section{A Closer Look at China's}

\section{Role in Changing Markets}

There is no clear evidence that direct competition from China would undermine NAFTA's benefits by displacing Mexico's textile and apparel exports to the United States. A simple test of correlation suggests that products from Mexico and China are not perfect substitutes. This finding implies that the liberalization of Chinese products is not solely responsible for changes in Mexico's share of the U.S. textile and apparel market.

China's products would need to be the most important substitutes for Mexican goods in order for
U.S. demand of Mexico's products to be threatened by an increase in the quantity of Chinese products in the U.S. market (see Figure 5). A simple test of correlation provides an indication of how sensitive Mexico's share of the U.S. market is to China's share. The correlation coefficient, Pearson's $r$, measures the strength and direction of a linear relationship between two variables. ${ }^{11}$ If two products are perfect substitutes, they have an inverse relationship; as one increases its share of the market, the other's share of the market decreases. Perfect substitutes have an rof -1 .

Analysis of data from the Office of Textile and Apparel (2005b) for 99 textile and apparel categories that the United States imports from both Mexico and China provides preliminary evidence about the relationship of Mexican and Chinese products in the U.S. market. After calculating Mexico and China's share of the U.S. market for each product category for the years 1989 and 2006, I calculated the change in market shate between these two dates for each product category. These calculations suggest that Mexico's share of the U.S. market decreased for these products as China's market share for these products increased and vice versa. This pattern indicates an inverse relationship represented by a negative $r$.

This data set produced an $r$ of $-.2394{ }^{12}$ If this accurately reflects the North American textile and apparel markets, this result indicates that Mexican and Chinese textile and apparel products are substitutes. More importantly, however, such a small absolute value for $r$ indicates a relatively weak relationship between the U.S. import market shares of Chinese and Mexican products. Mexico's share of the U.S. import market does not appear to depend directly on China's share of the U.S. import market and vice versa. Rather, research suggests the widespread quota elimination of the ATC will interact with Mexico's textile and apparel industries.

A study by Francois and Spinanger (2001) buttresses these findings and concludes that the entire ATC - as opposed to China alone-will reduce Mexico's trade preference and undermine NAFTA's benefits. Elimination of China's restrictions erodes only a portion of Mexico's trade preference. Francois and Spinanger (2001) present nine CGE models with different scenarios of ATC implementation using 1999 data. ${ }^{13}$ Francois and Spinanger's model isolates China's accession into the WTO ("Experiment $F$ " on page 5) 
shows that the elimination of quota restrictions on China is associated with a decrease in the value of Mexican textile exports by -1.96 percent as well as a decreases in apparel value of -8.42 percent (21-22, Table 6 and 7).

The model that encompasses the implementation of the entire ATC ("Experiment G" on page 5) shows that completed ATC is associated with a decrease in the value of Mexican textile exports of -6.32 percent and a decrease in the value of Mexican apparel exports of -33.71 percent (21-22, Table 6 and 7). Comparing Experiment $F$ with Experiment $G$, the impact of eliminating China's quotas constitutes only a portion of the total impact of the ATC on Mexico's export volume. China's influence does not entirely explain Francois and Spinanger's model of ATC completion; therefore, China cannot be entirely responsible for reducing Mexico's trade preference. This evidence suggests that global liberalization in apparel and textile trade undermines NAFTA's benefits rather than China alone. Therefore, protectionist policies against China will not prevent the erosion of prices, Mexico's trade preference, or Mexico's demand for U.S. products.

Mexico's trade preference to the U.S. market could exist only while the U.S. restricted other countries from its market. Restricting China alone will not bolster Mexico's trade preference. Restriction on 40 percent of U.S. textile and apparel imports created Mexico's trade preference in the 1990s (Evans and Harrigan 2005, 7-8). China's quotas alone could not have sustained Mexico's trade preference to the U.S. because China comprised only nine percent of U.S. apparel and textile imports in the 1990s. ${ }^{14}$ Therefore, evidence suggests that restrictions on many countties contributed to Mexico's trade preference before ATC completion, suggesting that China would need to capture 31 percent more of the U.S. market in order to be solely responsible for reducing Mexico's market share. This is an unlikely proposition considering the preponderance of newly unrestricted competitors.

\section{ThE IMPACT OF THE ATC ON China's Competitors}

China fails the correlation test and explains only part of Francois and Spinanget's (2001) model and Evans and Harrigan's (2005) estimate because other countries increased their exports when the ATC completed phasing out quantitative restrictions. Studies such as Andriamananjara et al. (2004), Francois and Woerz (2006), and Francois and Spinanger (2004) estimate the extent quotas restricted the production of individual countries prior to the elimination of the quotas. These estimates predict how much production will increase from a country based on how much quotas restricted production from that country. Logically, as quantitative restrictions relax, the exporting country's production and exports should increase. The mote restrained the country was before ATC completion, the larger the increase in production and exports will be after ATC completion. These studies show which countries other than China were restrained and, therefore, will increase production and exports. These countries will counter China's potential expansion of market share in the U.S. market.

The methods these studies employ estimate the amount of restriction on a country by measuring the economic rent generated by the quota system. In microeconomic theory, economic rent describes the portion of payment to a producer in excess of the amount necessary to induce the producer to supply the current amount of products (Browning and Zupan 2005, 478). ${ }^{15}$ The quota system limits supply, which increases market price to a level higher than it would reach without the quota system (see Figure 1). It limits some producers from the market and the producers with access to the market receive higher payments as a result of the higher price. In the quota system, economic rent describes the amount of payment received by the producer with preferential market access from the higher price.

The quota system created preference for individual producers within a restricted country. For example, most countries administered the quotas by creating a license for producers that granted them permission to export to the U.S. The licenses gave select producers 
market access while excluding producers without a license. A market developed for these licenses. The price producers would pay to obtain a license provides an estimate of the economic rent generated by the quota system (quota rent). th The price of the license can be thought of as an implicit tax on the exported product, an Export Tax Equivalent (ETE). Some exporting countries distribute their quota licenses through auctions. One way researchers estimate ETEs is by comparing the per-unit auction price of the quota license to the export unit values (Andriamananjara et al. 2004, 3-4, 9). 'The dollar amounts of ETEs serve as proxies for the quota rent used in estimating how tightly restrictions constrain a country.

Identifying the most restricted countries before ATC completion predicts which countries will increase their production and compete with China. The logic behind estimating restrictions suggests that the more binding the quotas, the more restricted is supply, and the higher the ETEs are priced. Following ATC completion, previously restricted countries will benefit in relation to how binding their former restrictions were; the more restricted, the more they benefit. The more these countries benefit, the more market access will diminish for countries that previously enjoyed preferential treatment. Based on findings from ETE estimates that low-income South Asian countries ${ }^{14}$ were more restricted than higher income East Asian countries ${ }^{11}$ in 1995 (Francois and Woerz 2006, 13), South Asian countries should increase supply and capture market share. Francois and Spinanger (2004) estimate that trade in textile and apparel will shift most dramatically toward China and India (4). They also project that China and South Asia had the highest ETEs of all the regions in 1992, before the ATC, in both textiles and apparel (19, Table 8). This indicates that these countries were the most constrained and ate thus more likely to experience a significant increase in exports with the elimination of quotas. Therefore, while economists expect the ATC to dramatically affect China, they also expect it to significantly affect other countries as well. These other countries will compete with China and limit China's market dominance.

Other studies come to slightly different conclusions in their predictions of country shares of the US. import market, but all concur with Francois and Spinanger's (2004) finding that countries in addition to China will significantly increase their exports and market shares. In estimating the impact of E.TEs on import share, Andriamananjara et al. (2004) show that import shate is highly responsive to changes in ETE. A one percentage point reduction in ETE is associated with an increase in a country's import share by 1.5 to 3.9 percentage points, depending on elasticity, holding all else constant. Therefore, highly constrained countries with high ETEs will experience reductions in ETEs and capture import share at a rate of one to 1.5-3.9 (Andriamananjara et al. 20014, 12). The authors estimate that the largest increases in shares in the U.S. textile and apparel import market (from a nine-country sample) will occur in Bangladesh, China, and Hong Kong, followed by India, pakistan and Macau (Andriamananjara et al. 2004, 12, 19 Table 6.) Yang et al. (1997) use CGE modeling to estimate that ATC completion will result in an increase in apparel exports in China, ASEAN ${ }^{21}$ and South Asian countries. The model shows that while all countries experience an increase in textile exports, apparel exports decline for Hong Kong, South Korea, Taiwan, and Latin America (Dean 2002, 13). While different models and estimations produce different results, all results support the argument that China is not the only country that will increase exports with the completion of ATC. The previous studies predict which countries will be China's main competitors as they increase their exports and potentially capture U.S. market share of textiles and apparel.

\section{Conclusion}

Critics concerned about how the liberalization of quantitative restrictions in the textile and apparel industries will affect North American textile and apparel manufacturers should think more broadly than the U.S. relationship with China. Indeed, when placed in the broader context of the ATC and its implementation and interaction with NAFTA, China's importance diminishes. Therefore, China does not portend the hegemonic role in the L.S. market reflected in the public debate. Removing quantitative restrictions on competitors-not just China-puts downward pressure on prices and, consequently, threatens jobs. 
The ATC undermines NAFTA's trade preferences and benefits, which enhances competitive pressure in North Ametican industries. While the decision of WTO members to implement the ATC negatively affects North American textile and apparel producers, China's entry to the WTO does not cause the adverse impacts feared by some. Rather than a single country, the global economic adjustment from a widespread reduction in trade barriers will affect the North American industries.

As the market adjusts to a new equilibrium under the ATC, North American manufacturers will experience intensified competition. According to both basic microeconomic theory and complex econometric models, supply will increase and prices will fall in the U.S. market. ROO will continue to require Mexico to purchase from the U.S. in order to sell in the U.S. market; however, the ATC is likely to undermine the preferential access those countries previously enjoyed when selling to the U.S. market.

Comparative advantage becomes more important in liberalized trade because competition intensifies. The U.S. manufacturing sector is finding it tougher to compete without protections that inflate prices above world market value. In part, this is because labor costs are considerably higher in the United States relative to many exporting countries. Nevertheless, the growth of China's economy and manufacturing capability is not inherently bad. China will increasingly provide a larger market for U.S. goods, which provides opportunity for U.S. firms while American consumers enjoy lower prices.

\section{Notes}

' See newspaper articles: Bradsher and Bajaj (2006); Barboza and Becker (2005).

${ }^{2}$ See newspaper articles: Andrews (2003); Bradsher (2006); Barboza and Becker (2005); Bloomberg (2005); Barboza (2005); Yingchun (2004); and Kanter and Bradsher (2005).

${ }^{3}$ See bills from the $109^{\text {th }}$ Congress: H.R. 2414; H.R. 3283; H.R. 3306; H.R.5043; H.RES.577; H.R.1498; and S.295. See newspaper articles: Andrews 2003); Kanter and Bradsher (2005); Lohr (2005); Bradsher (2006); Bradsher and Bajaj (2006); and Editorial (2006).

4 ibid.

${ }^{5}$ The Bretton Woods conference created GATT after WWII along with the World Bank and IMF to bring a structured negotiating forum to world trade. The intention was for GATT to evolve into an institution of international trade, which did not happen until the Uruguay Round (1986-1995) created the World Trade Organization. The WTO was the last agreement signed from the Uruguay Round in 1995 (World Trade Organization 2007).

${ }^{6}$ A quota only affects market price when it is binding. A quota is considered binding if the country's producers fill 85 to 90 percent of the quota (Evans and Harrigan, 8). In other words, if the quota is set higher than the country can produce of that item, the quota does not effectively limit supply and, therefore, does not impact market price. However, if the quota is set lower than the country can produce, the restriction is considered binding and the country's quota affects market prices. Back-loading means that the process did not relax binding quotas until the end of the phaseout, so market price was not effected until the end of the 10 year period. See Francois and Woerz (2006) for a detailed explanation of the phase-out process.

${ }^{7}$ When China joined the WTO in 2001, it agreed that countries could lengthen certain protections after the ATC deadline in 2005 if they experience import surges. In response to the import surge, China and the U.S. negotiated a reinstatement of quantitative restrictions on 34 textile and apparel product categories from January 1, 2006 to December 31, 2008 (Office of Textiles and Apparel 2005).

${ }^{8}$ While NAFTA was implemented in 1994 and the ATC in 1995, NAFTA promptly affected regional trade whereas the ATC did not affect the market until 2005 due to backlogging in the phasing-out.

${ }^{9}$ Writer's calculations based on the trade data from the Office of Textiles and Apparel's website http:// otexa.ita.doc.gov/ (accessed January 11, 2007).

${ }^{10}$ Writer's calculations from the Office of Textiles and Apparel's website http://otexa.ita.doc.gov/ expctry.htm (accessed January 11, 2007). 
${ }^{11}$ For variable $\mathrm{X}_{1}$ (Mexico's change in U.S. market share) and variable $\mathrm{X}_{2}$ (China's change in U.S. market share)

$$
r_{12}=\frac{\sum\left[\left(x_{1 i}-x_{1}\right)\left(x_{2 i}-x_{2}\right)\right]}{\sqrt{\left[\sum\left(x_{1 i}-x_{1}\right)^{2} \sum\left(x_{2 i}-x_{2}\right)^{2}\right]}}
$$

${ }^{12}$ Writer used STATA statistical software.

${ }^{13}$ Computable general equilibrium (CGE) models use microeconomic theory to predict equilibrium price and quantity values, which can result from changes in policy, based on data and assumptions about parameters (Deardoff 2006).

${ }^{14}$ Author's calculations of data collected from the Office of Textiles and Apparel's website http:// otexa.ita.doc.gov/scripts/tcads1.exe/catpage (accessed January 14, 2007).

${ }^{15}$ Economic rent that accrues to suppliers in the input market is analogous to producer surplus in the output market (Browning and Zupan 2005, 478).

16 The economic explanation in this paragraph uses information from Andriamananjara et al. 2004, pages 3 and 9. See Evans and Harrigan (2005), page 14, for further discussion of rent generated from inter-country preferential market access.

${ }^{17}$ Francois and Woerz (2006) discuss other approaches to estimating ETEs on page 4.

${ }^{18}$ Francois and Woerz (2006) did not indicate which countries they considered South Asian. Dean (2002) considered Bangladesh, Bhutan, India, Maldives, Nepal, Pakistan and Sri Lanka as South Asian.

${ }^{19}$ Francois and Woerz (2006) did not indicate which countries they considered East Asian. China, Hong Kong, Macau, Taiwan, North Korea, South Korea, Japan, and Mongolia are commonly considered as East Asia.

${ }^{20}$ Brunei Darussalam, Cambodia, Indonesia, Laos, Malaysia, Myanmar, Philippines, Singapore, Thailand, and Vietnam (Association of Southeast Asian Nations).

\section{REFERENCES}

Andrews, E.L. "Administration joins outcry against China trade policies." Neny York Times, 16 September 2003, Foreign Desk, sec. A1, p. 6.

Andriamananjara, S., J. Dean, and D. Spinanger. 2004. Trading apparel: Developing countries in 2005. Mimeo, U.S. International Trade Commission: Washington D.C. and Kiel Institute for World Economics: Germany (May).

Anson, J., O. Cadot, A. Estevadeordal, J. de Melo, A. Suwa-Eisenmann, and B. Tumurchudur. 2005. Rules of origin in North-South preferential trading arrangements with an application to NAFTA. Revien of International Economics 13(3): 501-517.

Association of Southeast Asian Nations (ASEAN), the official website, http://www.aseansec.org/ (accessed March 9, 2007).

Bloomberg News. "Trade Surplus in China Hit $\$ 5.6$ Billion in March." Nezy York Times, 12 April 2005, Business/Financial Desk, International Business, sec. C5, p. 4.

Browning, E.K., and Zupan, M.A. 2006. Microeconomics theory \& applications, $8^{\text {th }} \mathrm{ed}$. Hoboken, NJ: Willey.

Barboza, D. "China Trade Surplus with West Still Rising." The New York Times, 2 May 2005, Business/ Financial Desk, sec. C4, p. 2.

Barboza, D. and E. Becker. 2005. "Free of quota, China textiles flood the US." New York Times, 10 March 2005.

Bradsher, Keith and Vikas Bajaj. "International Business: as trade deficit grows, so do tensions with China." Newy York Times, 10 March 2006, Business Financial Desk, sec. C2, p. 1, late edition.

Bradsher, Keith. "China's trade surplus with U.S. surged in March." New York Times, 12 April 2006, Business and Financial Desk, sec. C1, p. 3, late edition.

Cadot, O., J. de Melo, A. Estevadeordal, A. SuwaEisenmann, and B. Tumurchudur. 2002. Assessing the effect of NAFTA's rules of origin. Research 
Unit Working Papers 0306, Laboratoire d'Economie Appliquee, INRA. http:// www.inra.fr/internet/Departements/ESR/UR/ lea/documents/wp/wp0306.pdf (accessed January 12,2007$)$.

Cadot, O., C. Carrere, J. de Melo, and A. PortugalPerez. 2005. How much market access in FTAs? Textiles under NAFTA. Discussion Paper Series, No. 5264. Center for Economic Policy Research, London (October).

Currency Rate Adjustment and Trade Enforcement Act of 2005, 109th Cong., 1 st sess., H.R. 2414.

Dean, J.M. 2002. Removing textile and apparel trade barriers: The impact on developing country exporters. A brief review of the literature. U.S. International Trade Commission, Washington, D.C. (May 22).

Deardoff, A.V. Deardoff's glossary of international economics. Updated 2006. http://wwwpersonal.umich.edu/ alandear/glossary/c.html (accessed December 22, 2006).

Editorial. "Mr. Schumer goes to China." Newy York Times, 27 March 2006, sec. A1, p. 18, late edition-final.

Evans, C.L. and J. Harrigan. 2005. Tight clothing: How the MFA affects Asian apparel exports. Edited by T. Ito and A. Rose. International Trade in East Asia: NBER-EASE Chicago: University of Chicago Press, 14:367-386.

Expressing the sense of the House of Representatives regarding the conditions for the United States to become a signatory to any multilateral agreement on trade resulting from the WVorld Trade Organization's Doha Development Agenda Round of $2005,109^{\text {th }}$ Cong., $1^{\text {st }}$ sess., H.RES.577.

Fair Trade with Cbina Act of $2005,109^{\text {th }}$ Cong., $1^{\text {st }}$ sess., H.R. 3306.

Francois, J. and D. Spinanger. 2001. With rags to riches but then what? Hong Kong's T\&C industry vs, the ATC and China's accession to the WTO. Paper prepared for the Fourth Annual Conference on Global Economic Analysis. Center for Global Trade Analysis: Indiana (June).

Francois, J. F. and D. Spinanger. 2004. Liberalizing quo- tas on textiles and clothing: Has the ATC actually worked? Paper presented at the annual Global Trade Analysis Project (GTAP) conference: Washington (June).

Francois, J. and J. Woerz. 2006. Rags in the high rent district: The evolution of quota rents in textiles and clothing. Discussion Paper, TI 2006-007/2. Tinbergen Institute: Rotterdam (December 28).

Lohr, S. "Advisory Commission Urges Congress to Get Tough on China Trade." The New York Times, 9 November 2005, Business/Financial Desk, sec. C1, p.3.

Kanter, James and Keith Bradsher. "A teturn to quotas; limits on textiles could push China toward making upscale goods." New York Times, 9 November 2005, sec. C1, p. 1, late edition-final.

Office of Textiles and Apparel. 2005a. Memorandum of Understanding Between the Government of the United States of America and the People's Republic of China Concerning the Trade in Textile and Apparel Products, November 8. http:// www.ustr.gov/assets/World_Regions/ North_Asia/China/asset_upload_file91_8344.pdf (accessed on May 8, 2006).

Office of Textiles and Apparel. 2005b. Trade Data. http://otexa.ita.doc.gov/ (accessed on May 8, 2006).

Restoring Americas Competitiveness Act of 2006, $109^{\text {th }}$ Cong, $2^{\text {nd }}$ sess., H.R. 5043.

Spinanger, D. 1999. Textiles Beyond the MFA PhaseOut. The World Economy. Blackwell Publishers, Ltd. 22 , no. 4 (June).

Chinese currency Act of $2005,109^{\text {th }}$ Cong., $1^{\text {st }}$ sess., H.R. 1498.

To authorize appropriate action if the negotiations with the People's Republic of Clina regarding Cbina's undervalued currency are not successfit of $2005,109^{\text {th }}$ Cong., $1^{\text {st }}$ sess., S.295.

United States Trade Rights Enforcement Act of 2005, $109^{\text {th }}$ Cong., $1^{\text {st }}$ sess., H.R. 3283.

Yang, Y, W. Martin, and K. Yanagishima. 1997. Evaluating the Benefits of Abolishing the MFA in the 
Uruguay Round Package. Global Trade Analysis: Modeling and Applications. Edited by T. W. Hertel. Cambridge: Cambridge University Press, 253-279.

Yingchun, M. "Textile Quota Lifting: Bane or Boon?" China Daily, 12 November 2004.

World Trade Organization. 2007. The GATT years: from Havana to Marrakesh. http:/ /www.wto.org/english/ thewto_e/whatis_e/tif_e/fact4_e.htm (accessed on April 6, 2007). 


\section{APPENDIX}

FIgURE 1: QUOTAS ON PRoDUCts DECREASE SUPPLY AND INCREASE PRICE

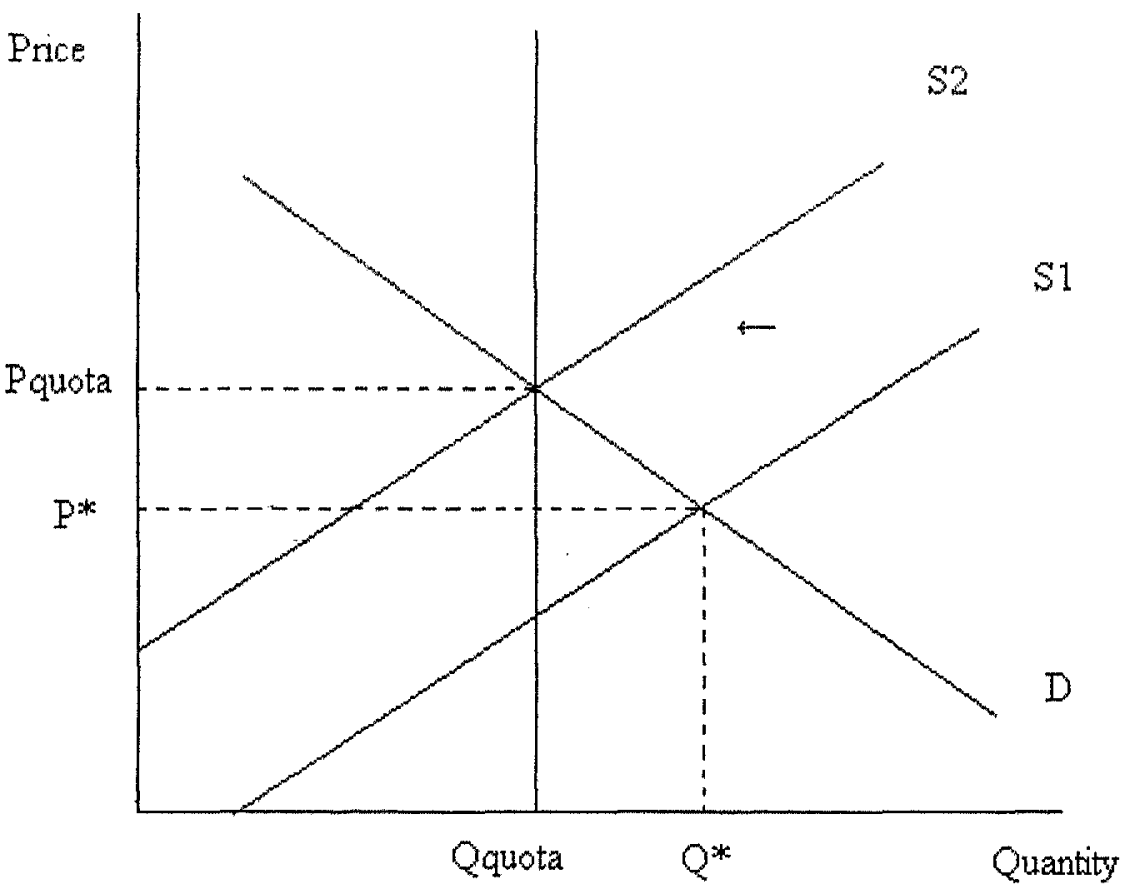

If the market equilibrium is at $\mathrm{Q}^{*}$ and $\mathrm{P}^{*}$, imposing a quota would decrease supply, shifting the supply curve to the left, putting upward pressure on price. If a product had a quota limit at $\mathrm{Q}_{\text {quofa, }}$, the price would be at $\mathrm{P}_{\text {oputan }}$. 
Figure 2: BenEFits of TRADE Preference

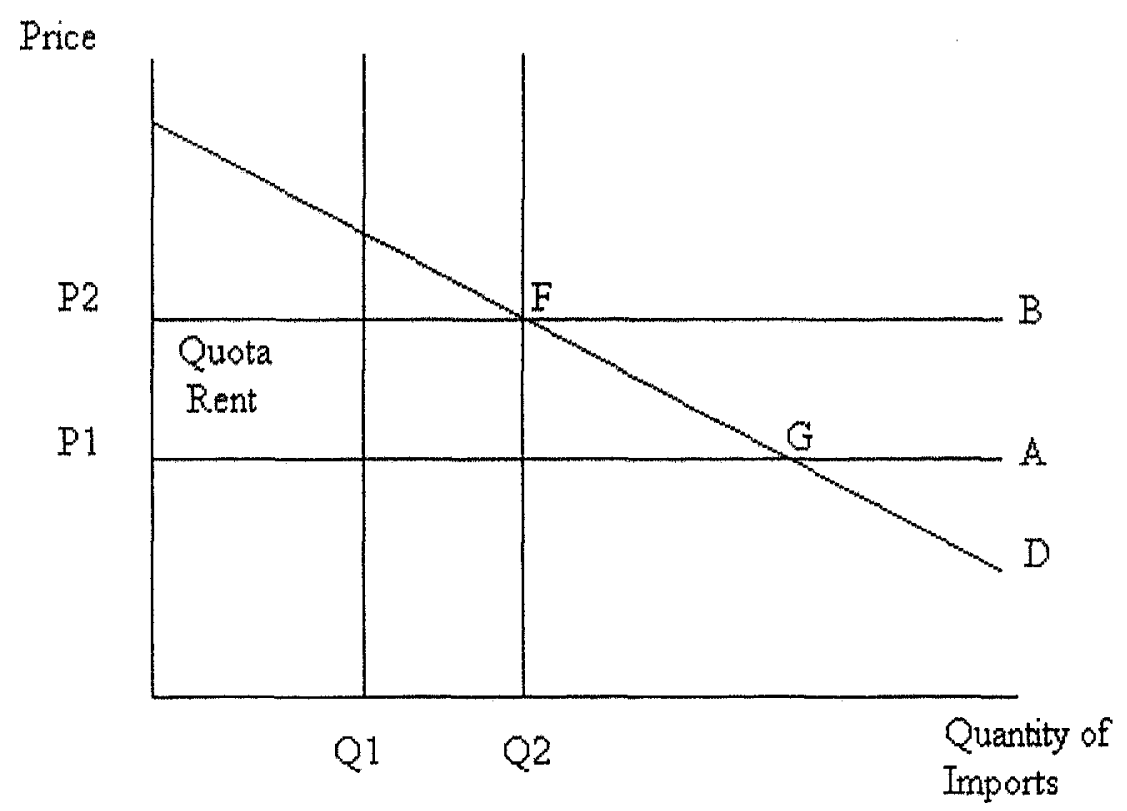

A: Countries with binding quotas

B: Countries with preferential market access

Country A has more efficient producers than Country B and would capture all demand (at $G$ ) if no quotas restricted their trade. The restricted supply at $Q 1$, because of quota restrictions, puts upward pressure on price until it meets the price at which Country B meets demand (at F). Country B supplies the quantity between Q1 and Q2. The importing price is higher at F than it would be without quota restrictions. The quantity supplied at $F$ is also lower than it would be without quota restrictions. The quota rent goes to firms in Country $\mathrm{A}$ that have the quota license, while firms in Country A without the license lose. Both countries charge the same price, $P_{2}$, even though one is bound by quota and the other is not. If the quota restriction is relaxed such that Q1 increases more than Q2, the importing price will lower.

Figure 2 is based on a graph in Evans and Harrigan (2005). 
Fugure 3: Mexico's Trade Preference

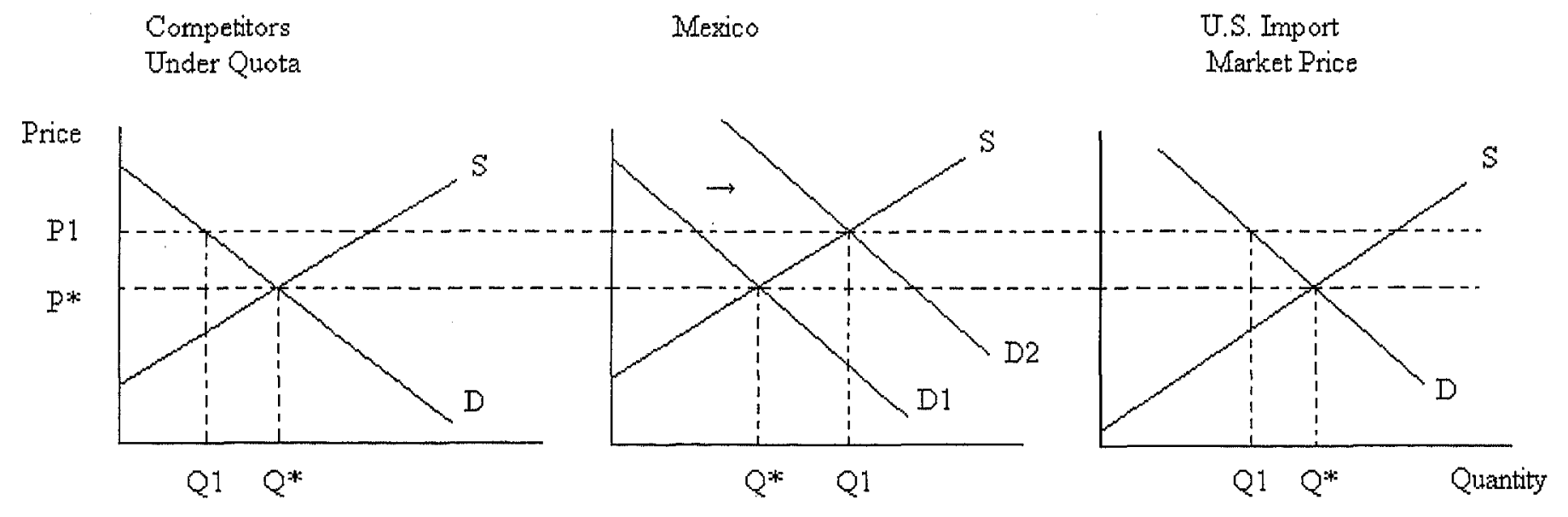

If market equilibrium is at $Q^{*}, P^{*}$ when a quota is placed on Mexico's competitors, the competitors must limit supply at Q1, putting upward pressure on U.S. Import Market Price. Without a quota, Mexico experiences an increase in demand for its product, and can increase quantity supplied at the higher price. If the competitors are more efficient than Mexico, Mexico's increase in quantity supplied when its competitors decrease quantity supplied would be considered trade diversion. 


\section{FIGURE 4: RULES OF ORIGIN}

Mexican Producer's Cost Curves

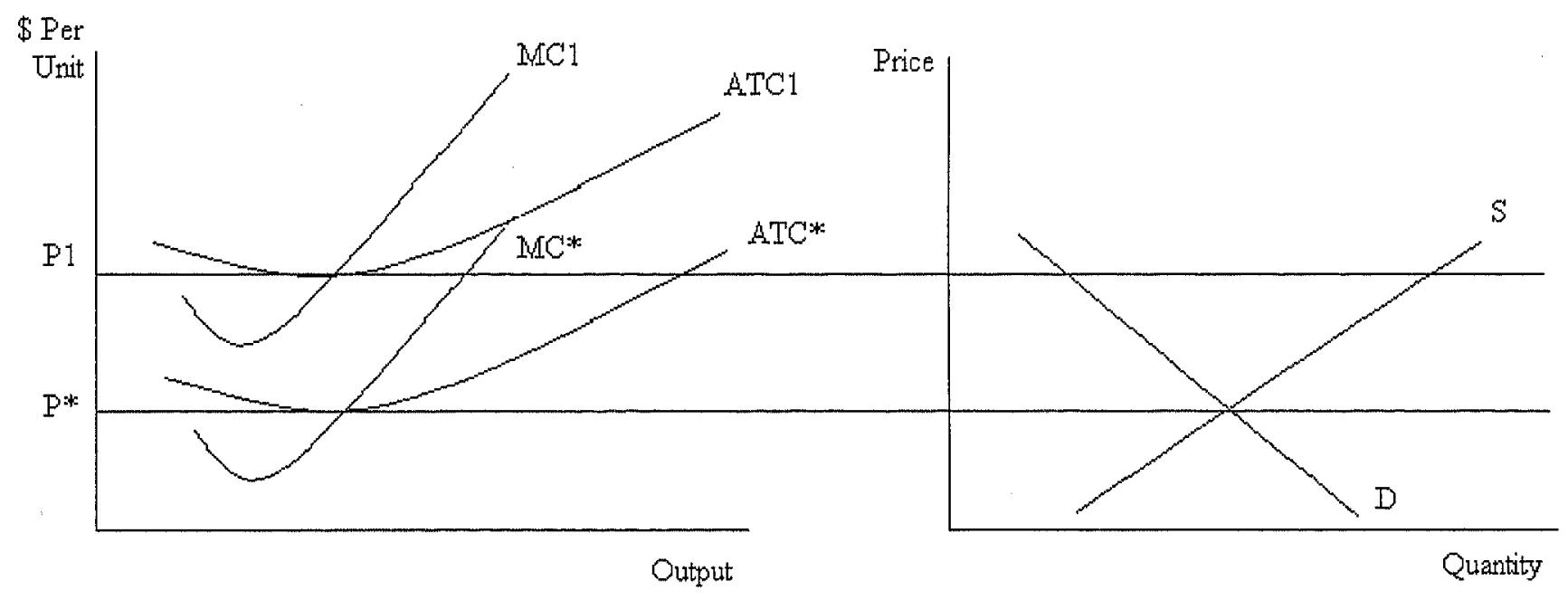

Rules of Origin create a higher input price that shifts a Mexican producer's marginal cost curve and average total cost curve up. The graphs show that the price that would keep Mexico at zero economic profit is P1, the price that is distortedly high in the U.S. market because of quotas that limit supply from other countries. Zero economic profit occurs when price equals minimum average total cost. The graph also shows that if the U.S. market's price decreased to equilibrium without quotas, $\mathrm{P}^{*}$, the Mexican producer would be operating below the minimum level of average cost because the Rules of Origin would keep costs at $\mathrm{MCl}$ and $\mathrm{ATC} 1$. Having to operate at an average cost of ATC1 while the market requires Mexican producers to reduce average cost to $\mathrm{ATC}^{*}$ in order to remain competitive would cause some Mexican producers to shut down. 


\section{FIGURE 5; SUBSTITUTION}

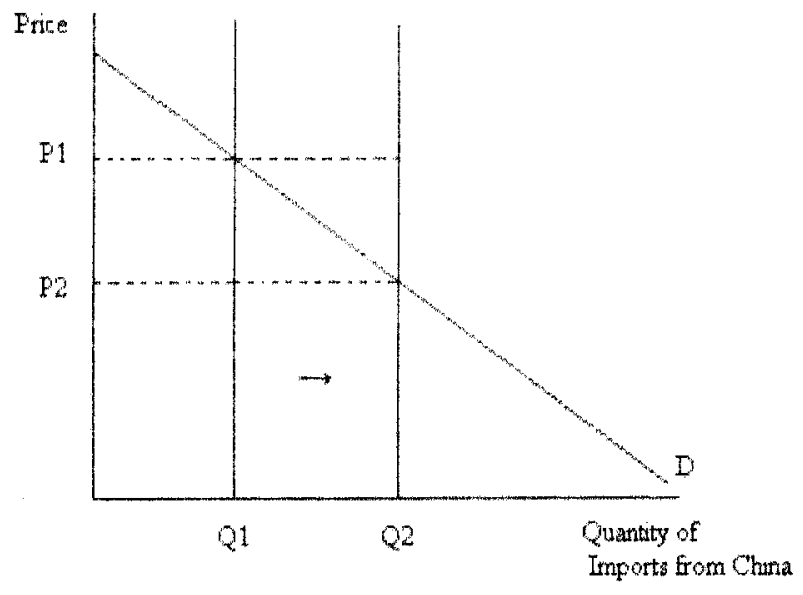

If China is bound by quotas, relaxing the quotas would allow quantity of imports in the U.S. market from China to increase from $\mathrm{Q} 1$ to Q2, which would put downward pressure on price to $\mathrm{P} 2$.

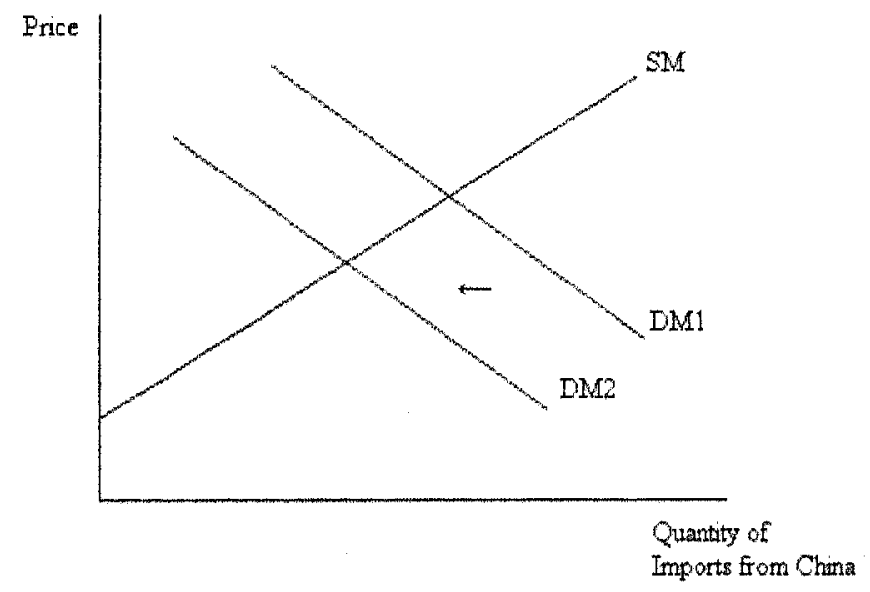

When the quota relaxes on China, the demand for the products from Mexico decreases, shifting demand to the left (DM1 to DM2).

Figure 5 is based on graphs in Evans and Harrigan (2005). 